\title{
The Effect of Indirect Written Corrective Feedback on Students' Writing Accuracy
}

\author{
Fastha Bagus Shirotha \\ fshirotha@gmail.com \\ Muhammadiyah University of Malang \\ Jl. Raya Tlogomas 246 Malang, Jawa Timur, Indonesia
}

Received: June 30, 2016; Accepted: August 20, 2016; Published: September 27, 2016

\begin{abstract}
Written corrective feedback has proven to be a key tool to improve students writing. Many previous researchers have proven so. Teacher gets to decide their very own written corrective feedback. There are many types of written corrective feedback that can be used in the classroom. They are direct written corrective feedback, indirect, and metalinguistic. The paper presents the effect of using indirect written corrective feedback to improve students' writing accuracy. The paper is intended to find the best written corrective feedback strategy in the classroom. The study is conducted to 35 low-proficiency ESL students. The writing pretest and posttest are used to measure students' writing accuracy. The researcher uses a t-test to analyze the data. The result is satisfying. 35 students have shown statistically significant progress in their writing accuracy. The posttest result has outscored the pretest score. Furthermore, it is also shown that indirect written corrective feedback also elicits students' autonomous learning.
\end{abstract}

Keywords: indirect written corrective feedback, teacher feedback, writing accuracy

How to cite this paper: Shirotha, F. B. (2016). The Effect of Indirect Written Corrective Feedback on Students' Writing Accuracy. Journal on English as a Foreign Language, 6(2), 101-118. 
There has been an outstanding effort in improving students' writing accuracy. Both researcher and teacher have sought ways to do that. They try one teaching approach after another, one method after another, one strategy after another.

A Recent study had used particular strategies to improve students' writing. The result of the study is satisfactory. Sabarun (2011, p. 46) conducted a Classroom Action Research. He used Cooperative Learning strategy to improve students' writing ability. The usage of two models Cooperative Learning which is a group discussion and Cooperative Integrated Reading and Composition successfully made the students able to achieve the minimum criteria prescribed for successful essay writing. He also mentioned that the teacher should correct the students' written work by underlining the grammatical errors, giving comments, giving back, and scoring the students' written work.

Then, another study also seeks the way to teach writing better. Miftah (2015a, p. 17) found that the implementation of a Writing Process Approach (WPA) can enhance the students' skill in writing a descriptive essay. The WPA consists of five stages. The first stage is a prewriting stage. It is meant to help the students collect ideas, viewpoints, or ideas related to the topic being discussed. Second, it is drafting stage. It provides the students' chance to write based on mapped ideas. Next, the revising stage is the third stage. The third stage is intended for the students to revise their first draft with an emphasis on content and organization. Then, the fourth stage is editing. It allows the students to edit the draft and proofread the draft for accuracy and correctness in spelling, punctuation, capitalization and grammar. Last, the final stage is publishing. The students are given chances to publish their final composition. The activities of publishing can be done in many ways. For example, the students are allowed to read their writing in front of the class or send it to school magazine.

Written corrective feedback is one of the instructions. The instruction has been a major debate since Truscott (1996, p. 354) published his paper. He acknowledged his opinion that written corrective feedback should be abandoned because it harms students' writing.

Furthermore, Truscott said that there was no solid proof confirming that error correction helped students' writing. He also said that error correction neglected the aspect of SLA about how languages are learned and acquired. Then, there was a practical problem toward students' and teachers' compliance to do such exhausting error correction. Surely, error correction is time and energy consuming. 
Then, there is the other side of the theory. Ferris (2004, p. 176) proved that Truscott's theory was work of flaw. She stated that through written corrective feedback, the students were able to edit and revise their texts. The short-term effect of written corrective feedback on text revisions had constantly established improved students' writing accuracy. The long-term effect of written corrective feedback was the students' writing accuracy gains over time. Then, written corrective feedback has a great acceptance from both students and teachers.

The error correction is not completely useless and harmful. Error correction could be seen as a meaningful input. Polio (2012, p. 384) argued that it is possible that some forms of error correction could serve as a trigger. Then the possibility remains that it may be seen as a way to speed up processability theory.

A cognitive perspective theory has an insight toward error correction. The information processing models see SLA as a building up knowledge that can be called on automatically by learners. Bitchener and Ferris (2012, p. 13) illustrated that the model accommodated a view that information may be processed in either in a controlled or automatic manner that swift a controlled learning toward automatic processing. It explained that intentional learning, such as error correction, can play role in the controlled phase and through practice or repeated activation over time become automatized.

The error correction also improved students' critical thinking skill. Farrah (2012, p. 195) found that peer feedback enhanced critical thinking skill as well as writing accuracy. The study also found additional results. The students also improved their ideas to write, were more motivated to write and had much better perception. Peer feedback requires the students to engage with collaborative learning. The finding also corroborates Miftah's (2015b, p. 643) finding. The most improved areas in peer feedback were content and grammar. He also noted that the suitable area between peer response and writer expectation was in terms of grammar accuracy. Both of the researchers involved English Department students as the participants.

A peer feedback, however, has several weaknesses. Ting and Qian (2010, p. 97) conducted a small research on a Chinese EFL writing class. They found that peer feedback improved slight improvement in accuracy but no significant improvement in grammatical or lexical complexity. Later, they noted that peer review is important, but peer review training may decide the effectiveness of peer review activity. Farrah (2012, p. 199) also stated that students should be trained intensively on how to carry peer feedback. 
The error correction should be done by the teacher. The teacher merely has better linguistic knowledge. Besides, Sheen and Ellis (2011, p. 600) revealed the obstacles with learners' self-correction. First, learners typically prefer the teacher to do the correction for them. Next, learners can only self-correct if they possess the necessary linguistic knowledge. Last, although output, prompting error-correction strategy signals that there is some kind of problem with learners' utterance; they do not make it clear that the problem is linguistic or communicative. The peer feedback, however, should not be put aside. A suitable usage of peer feedback will also improve students' writing.

Some might say that a mere practice would be sufficient to improve students' writing. Practice and exposure do have an impact on improving students' skill. However, Chandler (2003, p. 280) had a proof that it would be an understatement. He conducted a study involving East Asian college students in 10 weeks period. The result was amazing. He stated that a mere practice produced a significant improvement. However, a mere practice without error correction did not produce correct subsequent writing. Moreover, Ellis, Sheen, Murakami, and Takashima (2008, p. 368) found that written corrective feedback can be effective in promoting greater grammatical accuracy in both error correction test and in a new piece of writing. Then, they indicated that written corrective feedback can be effective in an EFL context as well as in ESL context.

There are several strategies to answer energy and time-consuming issue. Ferris (2011, p. 109) proposed several ideas to avoid burnout and make the written corrective feedback efficient and satisfying. First, the teacher sets realistic goals. The written corrective feedback should be seen as an effort to encourage gradual and consistent accuracy rather than to eradicate students' error. Next, the teacher should make most of the feedback indirect, focused, and verbal (not codes or symbol). Last, the teacher should gradually limit the feedback as the time goes on. The action should be done as a means for the students to take responsibility for their own writing. The students will learn to self-edit in a long term goal.

There are also several tips to survive written corrective feedback treatment. Guennete (2012, p. 121) proposed several ideas. First, the teacher should not adopt a one-size-fits-all behavior. It means a written corrective feedback have a great impact on a particular problem. For example, a direct written corrective feedback will improve students' untreatable error. Meanwhile, an indirect written corrective feedback is suitable for students' treatable errors (Ferris, 2011, p. 36). Second, the teacher should be selective about what to correct. It is intended to train students' awareness of linguistic pattern. The teacher also has more time to focus on another classroom activity. 
Last, the teacher should train learners to self-edit. Self-edit trains students to become aware of linguistic problems.

More studies have found that written corrective feedback helped students' writing progress. Bitchener (2008, p. 115) found that written corrective feedback had a significant effect on students' writing accuracy. He conducted the study on ESL students for 2 months on English article system (the use of "a" for the first mention and the use of "the" for the subsequent mentions). The first experimental group using direct, written and oral metalinguistic and the third experimental group using direct and no metalinguistic outscored the control group who did not receive corrective feedback.

Next, Bitchener and Knoch (2009, p. 208) found that written corrective feedback also retained the effect over ten-month. They found that the students who received written corrective feedback outperformed students who did not receive written corrective feedback and the pattern continued over a ten-month. The implication of the study was that written corrective feedback has a longterm effect.

Moreover, the statement that error correction leads to simplified writing (Truscott, 1996, p. 355) has refuted by Van, Catherine, DeJong, and Kuiken (2012, p. 33). They found that the new texts were written by their subjects who received written corrective feedback were more accurate than those of learners who were allowed an extra opportunity to practice their writing skill. Then, the written corrective feedback did not lead the students to produce both less structurally and lexically complex writing.

Written corrective feedback is also effective to enable students' writing accuracy on the new text. Van et al. $(2012$, p. 31) found that comprehensive corrective feedback enables learners to enhance the linguistic correctness of a certain text during revision and on a new piece of writing. Receiving written corrective feedback proved to be more beneficial than self -correction without any available feedback. The positive effect of comprehensive written corrective feedback showed to be durable: accuracy gains on a new piece of writing. Moreover, they stated that even a single written corrective feedback treatment proved to be long lasting positive effect four weeks later.

Besides, written corrective feedback does not lead to simplified writing, it also pumps students' motivation. The students were generally happy with the usage of written corrective feedback in the classroom (Mahfoodh, 2011, p. 21). Furthermore, $\mathrm{Li}$ and $\mathrm{Li}(2012$, p. 43) also found the written corrective feedback pumps up students' motivation. The students thought that written corrective feedback helped to improve their writing and pumps up their motivation. 
Moreover, Kormos (2012, p. 398-399) stated that self-efficacy beliefs also interact with the development of interest. Through the feedback, learners receive with high regard to their performance. Therefore, learners become interested in the activity because they have confidence in their ability to succeed in the task. Thus, the finding denied Truscott's opinion that there was a practical problem toward students' attitude on error correction. However, there is still more work to be done on the correlation between written corrective feedback and students' motivation.

Written corrective feedback also has an effect on students' explicit knowledge. Metalinguistic written corrective feedback has developed students' explicit knowledge (Shintani \& Ellis, 2013, p. 302). Metalinguistic enabled learners to develop their explicit knowledge of the indefinite article rule and to make use of this knowledge when revising and writing a new story. The participants of the study were learners with low proficiency. The implication of the study was that the written corrective feedback can be used across proficiency level. If written corrective feedback can be used to low proficiency level, then it can be used for advanced level students.

A recent study supported the argument. Educational level does not play an important role in the acquisition of written corrective feedback. Van et al. (2012, p. 33) never found a significant interaction between the effectiveness of the written corrective feedback treatment and learners' educational level.

Furthermore, Shintani and Ellis (2015, p. 118) stated that Language Analytic Ability did not play a pivotal role when the metalinguistic feedback is in nature. LAA is a factor in both processing metalinguistic explanation deductively and directs written corrective feedback inductively and then applying what they have learned in a new piece of writing. In short, written corrective feedback has an effect on students' writing regardless of educational and proficiency level.

The results of those previous researchers make a solid ground. The written corrective feedback has a great impact on students' writing development. Teacher gets to decide the kinds of written corrective feedback to use. As the things go, there is no reason to abandon written corrective feedback strategies in the classroom. Written corrective feedback has proven to improve both writing accuracy and students' motivation.

There are several written corrective feedback strategies that can be used in the classroom. As mentioned by Ellis (2009, p. 98-99), there are six strategies that can be implemented in the classroom so the strategies are fruitful. The written corrective feedback strategies are listed in Table 1. 
Table 1. Strategies for Providing Written Corrective Feedback

\begin{tabular}{|c|c|c|}
\hline No & Type of written corrective feedback & Description \\
\hline 1 & Direct written corrective feedback & $\begin{array}{l}\text { The teacher marks the error and } \\
\text { provides students with the correct } \\
\text { form. }\end{array}$ \\
\hline \multirow[t]{3}{*}{2} & Indirect written corrective feedback & $\begin{array}{l}\text { The teacher indicates that an error } \\
\text { exists but does not provide correction. }\end{array}$ \\
\hline & Indicating + locating the error & $\begin{array}{l}\text { This takes the form of an underlining, } \\
\text { marking, circling, crossing and use of } \\
\text { cursors to show omissions in the } \\
\text { students' text. }\end{array}$ \\
\hline & Indication only & $\begin{array}{l}\text { This takes a form of an indication in } \\
\text { the margin that an error or errors } \\
\text { have taken place in a line of a text. }\end{array}$ \\
\hline \multirow[t]{3}{*}{3} & $\begin{array}{l}\text { Metalinguistic written corrective } \\
\text { feedback }\end{array}$ & $\begin{array}{l}\text { The teacher uses metalinguistic clues } \\
\text { as to the nature of the error. }\end{array}$ \\
\hline & Use of the error code & $\begin{array}{l}\text { The teacher writes codes in the } \\
\text { margin (e.g. ww= wrong word; art= } \\
\text { article; v= verb error). }\end{array}$ \\
\hline & Brief grammatical descriptions & $\begin{array}{l}\text { The teacher numbers the errors in the } \\
\text { text and writes a grammatical } \\
\text { description for each numbered error } \\
\text { at the bottom of the text. }\end{array}$ \\
\hline \multirow[t]{3}{*}{4} & The focus of the feedback & $\begin{array}{l}\text { This concerns whether the teacher } \\
\text { attempts to correct all (or most) of the } \\
\text { student's errors or select one or two } \\
\text { specific error types to correct. }\end{array}$ \\
\hline & Unfocused WCF & Unfocused WCF is extensive. \\
\hline & Focused WCF & Focused WCF is intensive. \\
\hline 5 & Electronic written corrective feedback & $\begin{array}{l}\text { The teacher indicates an error and } \\
\text { provides a hyperlink to a concordance } \\
\text { file that provides examples of correct } \\
\text { usage. }\end{array}$ \\
\hline 6 & Reformulation & $\begin{array}{l}\text { This consists of a native speaker's } \\
\text { reworking of the student's entire text } \\
\text { to make the language seems as native- } \\
\text { like as possible while keeping the } \\
\text { content of the original intact. }\end{array}$ \\
\hline
\end{tabular}

Source: Ellis, 2008

Journal on English as a Foreign Language, 6(2), 101-118

Copyright @ 2016 by JEFL, p-ISSN 2088-1657; e-ISSN 2502-6615 
In addition, there is students' response toward written corrective feedback. This is done in order to maximize the effect of written corrective feedback. Table 2 explains the students' response toward written corrective feedback.

Table 2. Students' Response

\begin{tabular}{lll}
\hline No. & \multicolumn{1}{c}{ Response } & \multicolumn{1}{c}{ Description } \\
\hline Students' response & $\begin{array}{l}\text { For feedback to work for either } \\
\text { redrafting or language learning, } \\
\text { learners need to attend to the } \\
\text { corrections. Various alternatives exist } \\
\text { for achieving this. }\end{array}$ \\
\hline $1 \quad \begin{array}{l}\text { Revision required } \\
\text { The students are obliged to revise } \\
\text { the error based on the feedback. }\end{array}$ & $\begin{array}{l}\text { No revision required } \\
\text { The students are asked to study } \\
\text { corrections } \\
\text { The students are just given back the } \\
\text { corrected text. }\end{array}$ \\
\hline
\end{tabular}

Source: Ellis, 2008

Therefore, the teacher faces a deluge of written corrective feedback options. The teacher should pick the best option to implement it. As the things stand, direct and indirect written corrective feedbacks are the viable options. Since the metalinguistic feedback requires that both teacher and students possess a great deal of metalinguistic knowledge. Next, the electronic feedback requires that both teacher and students work with a computer. Furthermore, a reformulation needs a native to be an analyst.

Therefore, since others written corrective feedback has a flaw in their implementation, the only options are only direct and indirect written corrective feedback. From those two, a teacher has to pick the best.

Direct written corrective feedback means that the teacher marks the error and provides the correct form. There are many forms of this direct written corrective feedback (Ellis, 2008, p. 99). They are crossing out unnecessary words, phrases, or morpheme; inserting words, or morpheme, and writing the correct form above or near the mistaken word. However, the direct written corrective feedback hinders students' autonomous learning and may not contribute to long-term learning.

On the other hand, indirect written corrective feedback requires the teacher only to mark the certain error without giving the correct form. Marking the error can be taken in a form of circling, underlining, and crossing. Lalande 
(1982, p. 141) stated that indirect written corrective feedback leads to guided learning and problem solving. It also encourages students to reflect on their linguistic form. Moreover, it leads to long term learning.

Another success story of indirect written corrective feedback was stated by Ferris (2011, p. 94). Indirect written corrective feedback forces students to be more reflective and analytical about their errors. The students are required to learn from process, leads to their autonomous learning which is beneficial for to their long life learning. Then, if the goal is to sustain improvement in students' writing, then indirect written corrective feedback is the best strategy. Furthermore, Ferris (2010, p. 190) stated that the students prefer indirect written corrective feedback.

However, the researcher needs proof that indirect written corrective feedback can be done in Indonesia. The second language learners from previous explanation and research have different socio-cultural from Indonesian language learners. Therefore, does indirect written corrective feedback have a significantly higher effect on students' writing accuracy?

\section{METHOD}

\section{Research Design}

The study employs a pre-experimental quantitative research. The researcher wants to reveal the effect of indirect written corrective feedback on students' writing accuracy. The pre-experimental research is an experimental research done without a control group (Latief, 2012, p. 96). The way to measure whether or not the certain treatment is successful is through pretest-posttest design. If the posttest outscored the pretest score, the treatment is considered successful. Otherwise, it is considered a failure.

\section{Participants}

The subject of the study is taken from the researcher's writing class. They are Indonesian college students. There are 35 students in the class majoring in the non-English department. The students are obliged to take an English program by the university. The English program is a program obliged by the university for the first two semesters. The program consists only of four English skills, listening, speaking, reading and writing.

\section{Treatment and Procedure}

The researcher uses the indirect written corrective feedback to treat comprehensive students' error. It means the researcher will mark all errors made by students regardless of error types. The choice is picked because there is little known about written corrective feedback background research in 
Indonesia. The treatment also includes teacher conference in order to maximize the effect. Therefore, the research is intended to be the base of written corrective feedback research in Indonesia.

The treatments are given in five meetings. The first meeting is used as the pretest. The second, third, and fourth meeting are intended to do the treatment. The final meeting is used as the posttest meeting.

In doing the research, the researcher does these steps. First, the prompt writing pretest is given at the first meeting. Then, the first composition is given indirect written corrective feedback, scored, and given back to students. Third, the students are asked to revise their first composition. Next, the students are given the second writing prompt. Fifth, the second composition is given indirect written corrective feedback and returned to the students to be revised. Then, the fourth and fifth steps are repeated until the students are given the fourth writing prompt. Seventh, the final writing prompt is given to the students as the posttest. Last, the posttest is given indirect written corrective feedback, scored and returned to the students.

\section{Instrument}

The instruments used in the research are pretest and posttest writing. The writing test is developed based on the tests' needs. The tests are intended to measure the students' accuracy in writing, so the double test would be an assessment test.

Then, the researcher makes a writing prompt. The writing prompt should have instruction. The instruction has to be clear on how many paragraphs and timed controlled (Putra, 2011, p. 11). The writing prompt is open-ended and encourages students to write a narrative essay based on the two provided ideas in thirty minutes. Then, the instruction of writing prompt should ask the students to write the essay that consists of three paragraphs namely introductory, body and concluding paragraph. Next, the writing prompt also informs students that their writing will be scored upon the organization, adequate vocabulary, flawless language use, and accurate mechanics.

Then, the researcher makes a scoring rubric. There are three types of rating scores in scoring writing. They are holistic, primary trait and analytic (Putra, 2011, p. 14). The researcher decides to use an analytical scoring rubric. The analytic method attempts to evaluate separately the various components of a piece of writing. Therefore, the scoring rubric is based on two major parts. First, it is a rubric measuring students' work on organization. Second, it is a part scoring students' work on their language. 
However, writing is prone to subjectivity. Therefore, the researcher involves an inter-rater. The inter-rater works individually and separately in scoring the students' compositions. After finishing the compositions, the researcher, and the inter-rater meet to add and divide the score to determine the final score.

\section{FINDINGS}

The data obtained will go through a normality assumption test. It is intended to measure whether or not the data has a normal distribution. The researcher picked a Kolmogorov-Smirnov test. The result of the test can be seen in Table 3.

The significance level for this test will yield between 0 and 1 . The hypothesis for this test is that if the significance level is $<.05$, the data is considered to be abnormal. Therefore, the abnormal data will go through a nonparametric test. On the other hand, if the significance level yields $>.05$, the data is considered to be normal. As a result, the normal data will go through a parametric test.

Table 3. Normality Assumption Test

One-Sample Kolmogorov-Smirnov Test

\begin{tabular}{|ll|r|r|}
\hline & & Writing_pre & Writing_post \\
\hline$N$ & 35 & 35 \\
Normal & Mean & 66.57 & 69.94 \\
Parametersa,b & Std. & 3.54 & 3.79 \\
& Deviation & & \\
Most Extreme & Absolute & .11 & .12 \\
Differences & Positive & .11 & .12 \\
& Negative & -.11 & -.10 \\
Kolmogorov-Smirnov Z & .68 & .72 \\
Asymp. Sig. (2-tailed) & .74 & .67 \\
\hline
\end{tabular}

a. Test distribution is Normal.

b. Calculated from data.

Table 3 has shown that the significance level for both tests is $>.05$. The significance level of writing pretest yielded .74. Then, the significance level of writing posttest yielded .67. The significance level from both tests yielded $>.05$, hence the researcher went to the hypothesis test using the parametric test and the t-test.

First, the paired t-test is used to determine the hypothesis test. The paired t-test is chosen because it is the best way to determine two sets of data, whether or not they have a statistically different significant level.

The researcher had to find the means from both tests. The means from both tests can be seen in Table 4 .

Journal on English as a Foreign Language, 6(2), 101-118

Copyright (C) 2016 by JEFL, p-ISSN 2088-1657; e-ISSN 2502-6615 
Table 4. Writing Score Means

Paired Samples Statistics

\begin{tabular}{|r|r|r|r|r|}
\hline & Mean & N & \multicolumn{1}{c|}{$\begin{array}{c}\text { Std. } \\
\text { Deviation }\end{array}$} & $\begin{array}{c}\text { Std. Error } \\
\text { Mean }\end{array}$ \\
\hline Pair 1 Writing_pre & 66.57 & 35 & 3.54 & .59 \\
Writing_post & 69.94 & 35 & 3.79 & .64 \\
\hline
\end{tabular}

Based on Table 4, the writing pretest's means was 66.57 with 3.54 as the standard deviation. The writing posttest's means was 69.94 and the standard deviation was 3.79. This shows that the posttest outscored pretest.

However, the researcher needed to know whether or not the result was statistically significant. Therefore, the researcher did the paired t-test. The hypothesis used in this research was:

H0: there is no significance difference between the writing pretest score and posttest score.

$\mathrm{H} 1$ : there is a significance difference between the writing pretest score and posttest score.

The criteria in testing were: $\mathrm{H} 0$ is denied if the significance level is $<.05$ or $\mathrm{HO}$ is accepted if the significance level is $>.05$.

Table 5. Writing Paired T-Test Result

Paired Samples Test

\begin{tabular}{|c|c|c|c|c|c|c|c|c|}
\hline & \multicolumn{5}{|c|}{ Paired Differences } & \multirow[b]{3}{*}{$\mathrm{t}$} & \multirow[b]{3}{*}{$\mathrm{df}$} & \multirow{3}{*}{$\begin{array}{l}\text { Sig. (2- } \\
\text { tailed) }\end{array}$} \\
\hline & \multirow[b]{2}{*}{ Mean } & \multirow{2}{*}{$\begin{array}{c}\text { Std. } \\
\text { Deviation }\end{array}$} & \multirow{2}{*}{\begin{tabular}{c|} 
Std. \\
Error \\
Mean
\end{tabular}} & \multicolumn{2}{|c|}{\begin{tabular}{|c|}
$95 \%$ Confidence \\
Interval of the \\
Difference \\
\end{tabular}} & & & \\
\hline & & & & Lower & Upper & & & \\
\hline $\begin{array}{r}\text { Pair } 1 \text { Writing_pre - } \\
\text { Writing_post }\end{array}$ & -3.37 & 1.37 & .23 & -3.84 & -2.90 & -14.51 & 34 & .00 \\
\hline
\end{tabular}

Based on Table 5, it is known that the significance level was .00. Therefore, the $\mathrm{HO}$ is denied. It means that there is a significant difference between the pretest and the posttest.

\section{DISCUSSION}

The t-test result shows that indirect written corrective feedback has a significantly higher effect on students' writing accuracy. Thus, it answers the statement of the problem. The significance level is .00, which means <.05. 
Therefore, H0 is denied. In other words, the posttest's score is statistically significantly higher than the pretest's score.

In Graph 1, the researcher illustrates the difference between the pretest and the posttest.

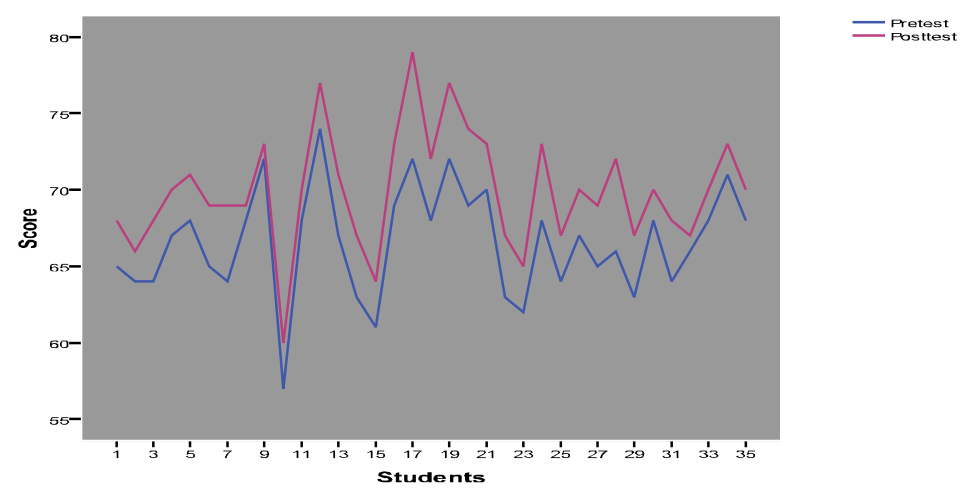

Graph 1. Pretest and Posttest Score

Based on Graph 1, it is seen that the students' are able to improve their writing accuracy. The red line represents the posttest score. Meanwhile, the blue line represents the pretest score. The red line is always above the blue line. It means the posttest is higher than the pretest score. In other words, the treatment successfully improves students' writing accuracy.

The finding also corroborates with the previous finding. As stated by Bitchener (2012, p. 353), the students who were treated with written corrective feedback improved their writing accuracy. The students showed improvement in their accuracy in both immediate posttest and delayed posttest. Therefore, the students demonstrated that they have attended information processing. As interactionist said, the students attended and noticed the feedback, understood the difference between the erroneous and the target-like, and applied the knowledge in a new piece of writing. The students also retained their level of improvement over time and stored in their long-term memory.

The students' writing on the pretest was ruined. Their verb was not spelled correctly. Then, there was also an error on subject-verb agreement. For example, the students wrote "she" as the subject, but they neglected to write "verbs". Next, the students wrote the verb did not base on the timeline, such as they wrote "go" for past tense sentence. Finally, the significant error was that their sentence neither has subject nor verb.

Moreover, the students neglected to write a capital letter at the beginning of a sentence. They omitted the very basic rule in writing. Besides, they also forgot to put a full stop at the end of a sentence. This mechanical problem was mind- blowing. The problems were complex. 
Another problem to address was that the writing seemed to be the work of a translator machine work. The writing is in English, but it sounds like Bahasa that is literally translated into English with the help of a translator machine. It sounded like Bahasa. It was like the students thought the sentence in their first language, Bahasa, and then they translated into second language, English.

At the posttest, the students had shown a modest progress. Their spelling was getting better. They got their verb form correctly. Their subject started to agree with the verb. This improvement made a good progress with students' writing accuracy, partly due to the implementation of indirect written corrective feedback. Hence, the finding broke Truscott's theory as well.

The noticed improvement was that the students never made the same mistake twice. Once students made mistake on one word, for instance, students wrote "go" instead of "went" for past tense, they tended not to make the same mistake for the second time. It means that the students produce correct subsequent writing. Moreover, it also indicates that indirect written corrective feedback leads to an autonomous learning.

The mechanical problem appeared at the pretest was not as many as at the posttest. The students started their sentence with a capital letter. Then, they also ended their sentence with a full stop. The mechanical problem was solved by using indirect written corrective feedback. There was a little error in mechanical problem appeared at the posttest.

One thing that should be taken more into account was the feel of Bahasa on students' writing. This might deal with treatable and untreatable error (Ferris, 2011, p. 36). A treatable error is related to a linguistic structure that occurs in a rule-governed way. It is treatable because the students can be pointed to a grammar book or set of rules to resolve the problems. For example, a treatable error lies on verb tense and form, subject-verb agreement, article usage, plural and possessive noun endings, sentence fragments, run-on and comma splices, errors in word form, errors in punctuation, capitalization, and spelling. An untreatable error is idiosyncratic, and students will need to utilize acquired knowledge of the language to self-correct it. An untreatable error includes most word choice errors, possible exception of some pronoun and preposition usage, and unidiomatic sentence structure. Furthermore, she also stated that the best way to treat treatable error is by using indirect written corrective feedback. On the other hand, direct written corrective feedback is better at treating untreatable error.

Furthermore, there are several conditions determining a successful written corrective feedback treatment. Bitchener and Ferris (2012, p. 857) indicated that information processing has pedagogical implications on written corrective feedback. The written corrective feedback should be clear and 
appropriate for the developmental of the students' proficiency. Next, the time of the treatment should be longer. The limitation of the study was that the treatment was given in five meetings. The problem should be addressed in the future research. Last, the students' socio-cultural background has an impact on students' goal, motivation, and attitude. Therefore, future investigation should seek more to the correlation toward written corrective feedback and individual differences.

Besides the unsolvable problem, it is good news for the teacher. The teacher is able to use written corrective feedback, especially indirect, as a strategy. The teacher can implement the indirect written corrective feedback confidently. Indirect written corrective feedback has proven to be a key tool in improving students' writing accuracy.

\section{CONCLUSION}

The study is intended to find the effect of indirect written corrective feedback on students' writing accuracy. Well, the answer does fulfill the researcher's expectation. The indirect written corrective feedback does statistically significant improve the students' writing accuracy. The implication of this research is great. The researcher hopes that the finding ends the endless debate among experts about the effect of written corrective feedback. Many previous researchers have found the exact same outcome. The finding put the written corrective feedback on stronger position.

The study does have several design flaws. However, this is a breakthrough on written corrective feedback area. As it is little known in the area in Indonesia, this research should be a base of other research in the field. Written corrective feedback has proven to be useful. It improves the students' writing accuracy. It pumps up the students' motivation as well. However, there is more work to be done in the area indeed.

Further research should be done in this area. There are many areas undiscovered in Indonesia, such as involving direct written corrective feedback for low level, using metalinguistic written corrective feedback for advanced level, and comparing direct and indirect written corrective feedback for low level. The research development in this area in a foreign country which uses English as their second language has been great. Indonesia has to catch up with the lack of published research in the area.

\section{REFERENCES}

Bitchener, J. (2008). Evidence in support of written corrective feedback. Journal of Second Language Writing, 17, 102-118. 
Bitchener, J. (2012). A reflection on 'the language learning potential' of written CF. Journal of Second Language Writing, 21, 348-363.

Bitchener, J., \& Ferris, D. R. (2012). Written corrective feedback in second language acquisition and writing. Routledge: New York.

Bitchener, J., \& Ferris, D. R. (2012). Written corrective feedback for L2 development: Current knowledge and future research. TESOL Quarterly, $46(4), 855-860$.

Bitchener, J., \& Knoch, U. (2009). The contribution of written corrective feedback to language development: A ten months investigation. Applied Linguistic Journal, 31(2), 193-214.

Chandler, J. (2003). The efficacy of various kinds of error feedback for improvement in the accuracy and fluency of L2 students writing. Journal of Second Language Writing, 12, 267-296.

Ellis, R. (2009). A typology of written corrective feedback. ELT Journal, 63(2), 97107.

Ellis, R., Sheen, Y., Murakami, M., \& Takashima, H. (2008). The effects of focused and unfocused written corrective feedback in an English as a foreign language context. System, 36, 353-371.

Farrah, M. (2012). The impact of peer feedbacks on improving the writing skills among Hebron university students. An-Najah University Journal Research (Humanities), 26(1), 180-210. (Online), Retrieved 28 August 2016 from https://journals.najah.edu/media/journals/full_texts/mpact-peerfeedback-improving-w riting-skills-among-hebron-universitystudents.pdf

Ferris, D. R. (2004). The "grammar correction" debate in L2 writing: Where are we, and where do we go from here? (And what do we do in the meantime...?). Journal of Second Language Writing, 13, 49-62.

Ferris, D. R. (2010). Second language writing research and written corrective feedback in SLA: Intersections and practical applications. Studies in Second Language Acquisition, 32, 181-201.

Ferris, D. R. (2011). Treatment of error in second language student writing ( ${ }^{\text {nd }}$ ed.). Ann Arbor: Michigan.

Guennete, D. (2012). The pedagogy of error correction: Surviving the written corrective feedback challenge. TESL Canada Journal, 30(1), 117-126.

Kormos, J. (2012). The role of individual differences in L2 writing. Journal of Second Language Writing, 21, 390-403.

Lalande, J. F. (1982). Reducing compositions errors: An experiment. The Modern Language Journal, 66(2), 140-149.

Latief, M. A. (2012). Research methods on language learning: An introduction. Malang: UM Press. 
Li, S., \& Li, P. (2012). Individual differences in written corrective feedback: A multi-case study. Canadian Center of Science and Education, 5(11), 38-44.

Mahfoodh, O. H. A. (2011). A qualitative case study of EFL students' affective reactions to and perceptions of their teachers' written feedback. Canadian Center of Science and Education, 4(3), 14-25.

Miftah, M. Z. (2015a). Enhancing writing skill through writing process approach. Journal on English as a Foreign Language, 5(1), 9-24.

Miftah, M. Z. (2015b). Peer response in an Indonesian EFL writing class: A case study. Proceedings of International Conference on Educational Research and Development (ICERD), UNESA, 5 December 2015. (Online), Retrieved 28 August 2016 from https://www.researchgate.net/publication/306346665_Peer_Response_in_ an_Indonesian_EFL_Writing_Class_A_Case_Study

Polio, C. (2012). The relevance of second language acquisition theory to the written error correction debate. Journal of Second Language Writing, 21, 375-389.

Putra, M. S. (2011). Appropriate writing assessment, how do we do it properly? Journal on English as a Foreign Language, 1(1), 9-16.

Sabarun. (2011). Improving writing ability through cooperative learning strategy. Journal on English as a Foreign Language, 1(1), 41-48.

Sheen, Y., \& Ellis, R. (2011). Corrective feedback in language teaching. In Hinkel, E. (ed), Handbook of Research in Second Language Teaching and Learning Volume II (593-610). New York: Routledge.

Shintani, N., \& Ellis, R. (2013). The comparative effect of direct written corrective feedback and metalinguistic explanation on learners' explicit and implicit knowledge of the English indefinite article. Journal of Second Language Writing, 22, 286-306.

Shintani, N., \& Ellis, R. (2015). Does language analytical ability mediate the effect of written feedback on grammatical accuracy in second language writing? System, 49, 110-119.

Ting, M., \& Qian, Y. (2010). A case study of peer feedback in a Chinese EFL writing classroom. Chinese Journal of Applied Linguistics (Bimonthly), 33(4), 87-98. (Online), Retrieved August 28, 2016, from http://www.celea.org.cn/teic/92/10120606.pdf.

Truscott, J. (1996). The case against grammar correction in L2 writing classes. Language Learning, 46(2), 327-369.

Van, B., Catherine, G., DeJong, N. H., \& Kuiken, F. (2012). Evidence of effectiveness of comprehensive error correction in the second language writing. Language Learning, 62(1), 1-41. 


\section{Author's Brief CV}

Fastha Bagus Shirotha graduated from Muhammadiyah University of Malang in 2011. He experienced teaching in several schools as a mentor since 2010. He began teaching in a private course at 2011. In 2012, he took his postgraduate degree in State University of Malang. He currently teaches as an instructor at Language Center at the Muhammadiyah University of Malang. 